\title{
Sustainable Development of an Island Tourist Destination: Example of the Island of Pag
}

\author{
Aleksandra Krajnović \\ University of Zadar, Department \\ of Economics, Croatia \\ akrajnov@unizd.hr
}

Ivica Zdrilić

University of Zadar, Department

of Economics, Croatia

izdrilic@unizd.hr

\author{
Nikolina Miletić \\ University of Zadar, Department \\ of Economics, Croatia \\ nikolina.miletic94@gmail.com
}

The purpose of this paper is to explore the issue of sustainable development of tourism in island destinations through the example of the island of Pag in Croatia. This paper aimed to find out the extent of sustainable tourism development on the island of Pag and to discover the factors influencing it. The primary research sought to determine what are the opinions and views of key tourism stakeholders about sustainable tourism on the island of Pag. The key research question in the paper is: Which model of tourism development is optimal for the sustainable development of the island of Pag as a tourist destination? The method of qualitative analysis was used, as well as primary research that combined interviews with experts and surveys. Furthermore, a comparative analysis of the research results has been performed using interviews and survey results. The research took place during 2019 on the island of Pag. Key stakeholders of tourism on the island of Pag were interviewed, as well as an employee of the Tourist Board of the City of Pag. According to the empirical research, it was found that sustainable tourism is developing poorly on the island of Pag. Sustainable tourism development implies responsible management of the area, with an emphasis on natural and cultural heritage, and aims to meet the needs of tourists and needs of current and future local communities. Sustainability and sustainable development of tourism, especially in the islands as extremely fragile geographical, economic, and socio-cultural entities, are of particular importance. In doing so, it is necessary to apply an integrated approach.

Keywords: sustainable tourism, mass tourism, sustainable tourist destination, seasonability, sustainable tourism on islands, the island of Pag

(cc)BY-SA https://doi.org/10.26493/2335-4194.14.23-37

\section{Introduction}

Sustainable tourism presents one of the major challenges when it comes to the social-economic and sociocultural development of each country and region focused on the development of tourism. However, this term, so often mentioned in real life and presented in strategic development plans, often remains at the level of the formal principle, since its application encounters numerous difficulties. Sunara et al. (2013, p. 83) considered that 'although sustainability is one of 
the most common concepts in tourism, a problem occurs when it is applied in real life.' The same authors state that the concept of sustainable development is based on meeting the needs not only of the present but also the future generation. 'It is important for a tourist destination to come up with a unique tourist offer that will meet the needs of tourists, without producing any negative impact on the environment, but rather govern the protection and sustainability of all tourism resources' (Sunara et al., 2013, p. 84).

The main sustainability challenges occur precisely at the local level, where different, often conflicting, interests arise when it comes to a tourist destination. Therefore, in this paper, the island of Pag in Croatia was taken as a specific example of a rapidly developing tourist destination on which to test the sustainability, or, respectively. sustainable development of tourism.

The purpose of this paper is to explore the issue of sustainability and sustainable development of tourism in island destinations. The primary research sought to determine what are the opinions and views of key tourism stakeholders about tourism on the island of Pag and about the level reached and key problems in the development of island tourism on Pag. The research questions posed in this paper are: What is sustainable tourism, and what is its significance in the development of tourism on islands? What are the goals of sustainable tourism, and how are they related to strategic planning in a tourist destination, based on the principles of an integrated approach to management? What are the geographical characteristics of the island of Pag, and what are the specifics of the development of tourism on the island? To what extent does the island of Pag care about the sustainable development of tourism? Which of the three key principles of sustainability - economic, socio-cultural, and environmental - do tourism stakeholders value the most when it comes to sustainable tourism? How important is it for the development of sustainable tourism to unite the brand of the island as a recognizable tourist destination?

The paper presents the results of the primary research performed by the method of a combination of expert interviews and surveys. Then, a comparative analysis of the research results was performed using interviews and survey results. The research was conducted in 2019 on the island of Pag in Croatia. Key stakeholders of tourism on the island of Pag were interviewed, as well as an employee of the Tourist Board of the City of Pag.

By researching the relevant literature, a research gap can be noticed when it comes to the development of tourism on the islands, especially when it comes to the Adriatic islands with their specifics. More comprehensive research that holistically looks at the issue of sustainable island tourism in the Adriatic dates back to twenty or even thirty years ago (see, for example, Mikačić, 1994; Vlahović, 2001). When it comes to foreign literature, the theory offers interesting case study analyses, such as Tioman Island, Malaysia ( $\mathrm{Ng}$ et al., 2017); Lakshadweep archipelago, India (Kokkranikal et al., 2003); the Island of Dominica (Lambert, 2009); Cat Ba Island, Vietnam (Mai \& Smith, 2015) and others. An interesting study is presented in the book Island Tourism and Sustainable Development: Caribbean, Pacific, and Mediterranean Experiences edited by Apostolopoulos and Gayle (2002), that highlights the key problems of sustainable island tourism based on the experiences of the Caribbean, Pacific, and Mediterranean islands. The same authors, in the introductory part of the book, point out that, 'as tourism is undoubtedly a vital component of the Caribbean, Pacific, and Mediterranean insular regions, our understanding of the ways it operates in the complex context of development is quite limited' (p. 12). A well-known theorist Cohen (2017, p. 7) speaks about a similar research gap, stating: 'Island studies and tourism studies have overlapping interests, but there was little interaction between them. [...] It is suggested that greater attention to this issue might be a facilitating factor in the convergence of island studies and tourism studies.' This paper was also written as a contribution to the research of these related phenomena - island studies and understanding the sustainability of island tourism.

\section{Sustainable Development of Island Tourism: Literature Review}

Čavlek \& Vukonić (2001) state that sustainable tourism is the ability of a tourist destination to remain bal- 
anced with the environment, i.e. the ability to remain competitive in the market despite the emergence of new and less-visited destinations and to attract both returning and first-time visitors, thus achieving enviable economic results while protecting and enhancing natural resources. Back in 1969, Becker noted that small islands exert a powerful attraction on tourists; their characteristic 'gestalt of remoteness, difference, distance, distinct culture and heritage, wilderness environment, and small size [constitutes] an attraction' (Brown \& Cave, 2010, in Cohen, 2017, p. 8). On the necessity of a holistic approach to researching the problems of island tourism development, Lim and Cooper (2008, p. 89) state that it is important to answer the question: 'How a complex and dynamic tourism system can be developed that takes a destination towards an optimal sustainable state to satisfy both visitors and the local community.'

One of the key research questions in this paper was whether tourism stakeholders believe that sustainable tourism should develop more on an economic, sociocultural, or environmental basis. A similar approach is taken by the editors of the book Island Tourism: Towards a Sustainable Perspective, Carlsen and Butler (2011), who structured the book according to these three principles. They point to the growing interest in research on sustainable island tourism development and state that the probable reason for this is 'the fact that islands form perfect "living laboratories" that enable researchers to isolate the causal and immediate effects of tourism development on the community, environment and economy of islands, and to study them at a level of detail that is not possible in other tourism destinations' (Carslen \& Butler, 2011, p. xii). Among earlier authors, we should point out the thesis of the Mikačić, who in her 1994 work emphasizes the essence of the issue of sustainable tourism on the Croatian islands, stating: 'Tourist facilities on the islands account for one-fourth of the overall Adriatic tourist offer. [...] Although its development has generally followed the coastal one, it took a more modest form so that the islands escaped many negative effects of mass tourism. In order to retain the existing advantages, the islands' development has to be harmonized with the environment while qualitative factors have to be given priority' (Mikačić, 1994, p. 517). Vlahović (2001, p. 229) states: 'On the islands, it is necessary to have long-term development programs, which automatically include the elaboration from spatial plans to the elaboration of implementing spatial plans in individual narrower tourist locations and zones.' Advocating for an integrated approach to management, or, as the author himself defines: 'measures and actions for holistic and more harmonious development ("integrated development"), he defines island resources as a 'wealth of nature and culture' and concludes: 'In fact, it is the most valuable spatial reserve for the development of the highest quality types and forms of tourism, of course, provided that natural and environmental values are permanently preserved.'

When it comes to tourism on the island of Pag, the research in this paper can be linked to earlier research presented in the paper by Bašić et al. (2015). In this paper, the authors, among other things, examined the opinions and attitudes of key stakeholders in the tourism of Pag, related to the branding of Pag as a spatial entity. Respondents answered that 'the island of Pag should be presented on the tourist market according to a unique umbrella brand' and further stated: 'It is necessary to jointly advertise the island as a whole and not as before where each tourist community "works for itself"'. They also believe that branding the island of Pag would achieve better, higher quality and sustainable tourism of the entire island destination. From the conducted research, the authors stated that very little work was done on branding the island of Pag as a spatial unit back then (2015), since, as the authors state, 'there is no single master plan for tourism development on the island of Pag and its D Mo (Destination Management Organization) that would put it into practice' (Bašić et al. 2015, p. 102).

Among the more recent literature, the research of Krstinić Nižić and Fugošić can be highlighted, which presented a model of sustainable development of an island destination on the example of Krk. They state that it is possible to incorporate development strategies of lower levels into a level covering a wider area, thus encouraging the development of all parts of the island of Krk, not just the developed ones. This should serve as an example to other units of local self-government in 
the Republic of Croatia, as well as in the world, to show that it is possible to act in harmony and line with the same objective by improving the quality of living for the present generation, but also for the generations to follow' (Krstinić Nižić \& Fugotić, 2019, p. 105).

\section{Sustainable Tourism vs. Mass Tourism: A Holistic Approach}

Bramwell and Lane (1993) noted that tourism has been increasingly turning towards sustainable development. They conclude that it offers some solutions, that is, it reduces misunderstandings and problems among stakeholders such as tourists, the local community, and the entire tourism sector. Krstinić Nižić and Drpić (2013, p. 160) emphasize 'the need to highlight the systematic implementation of measures and activities in the tourism industry of the Republic of Croatia, in ensuring sustainable development of a destination and in strengthening environmental awareness of all stakeholders.' Krajinović (2015) makes a similar statement, saying that sustainability is a very demanding and complex term included in numerous strategies, so every tourist destination should be engaged in its implementation as much as possible and concludes: 'The key factor in the sustainable development of a destination is the cooperation precisely and has a significant impact on the process performance success' (Krajinović, 2015, p. 69). As stated by Vukonić (2010, p. 37): 'Tourist destinations are most often guided by examples found in the professional literature, however, these examples most often come from underdeveloped areas that are sparsely populated, hence making sustainability management simpler. For this reason, it is impossible to accept such examples as an explanation of sustainable tourism, and especially not as a modality to introduce and manage sustainable development.' In this way, he builds on similar earlier theses of Jafari (1989) who asserted, 'Some authors have stated that the tourism biggest problem is its massive participation. However, when it comes to sustainable tourism, the problem is not in its extent but in the effectiveness of tourism management of a destination with an emphasis on its specificities.' Jadrešić (1999) emphasized even earlier the problem of mass tourism, which, in his opinion, is still dominant, stating: 'Although nowa-
Table 1 Difference between Mass and Sustainable Tourism

\begin{tabular}{ll}
\hline Mass tourism & Sustainable tuorism \\
\hline Unconstrained development & Controlled development \\
Quantity & Quality \\
Prominent seasonality & $\begin{array}{l}\text { Development of tourist } \\
\text { preseason and postseason }\end{array}$ \\
Reduced amount of & $\begin{array}{l}\text { Resources preservation - } \\
\text { higher level of }\end{array}$ \\
experience & consciousness \\
Mass marketing & Consumer direct \\
communication & communication \\
Mass markets & Specialized markets \\
Fast development & Slow development \\
Large groups of people & Individuals and families \\
Old tourist habits & New tourist habits \\
Existent destinations & Emerging destinations \\
Planned itinerary (travel & Spontaneous itinerary \\
program) & \\
Short-term tourism form & Long-term tourism form \\
\hline
\end{tabular}

Notes Adapted from Popesku (2011) and Butler (1999).

days tourists are starting to avoid mass tourism by looking for preserved and untouched places for their holidays, mass tourism is still not declining' (Jadrešić, 1999, p. 63). Although he wrote about this problem two decades ago, the problem of mass tourism is still ubiquitous. With increasing massive participation, the destination begins to lose quality and attractiveness and then competitiveness, so tourists are in pursuit of new destinations. Therefore, tourist destinations must make an effort to develop sustainable tourism for many reasons. The tendency to achieve environmental and social balance is essential for the preservation of the destination for the benefit of the local population and future generations. The change from mass to sustainable tourism is a long-term process of continuous improvement, and the differences between the two forms of tourism are shown in Table 1 (Popesku, 2011; Butler, 1999).

\section{Principles and Goals of Sustainable Tourism}

For sustainable tourism development, it is necessary to have a quality strategy development by applying 
three important principles of tourism sustainability: environmental, economic and socio-cultural principles (Klarin, 2017):

1. Environmental sustainability: effective use of natural resources of a destination which are crucial for the development of tourism. It is a question of maintaining and protecting biodiversity and natural wealth.

2. Socio-cultural sustainability: above all, it concerns building and preserving relationships of the local community, tradition, and cultural heritage. Intercultural respect and providing satisfaction to tourists is essential. Training and education programs to improve and manage heritage and natural resources are advised.

3. Economic viability: it is reflected in maintaining the economy of a tourist destination, that is, enabling sustainable business activities, increasing employment, and thus revenues for the purpose of achieving economic welfare.

Breslauer et al. (2015, p. 99) state: 'Local population and community, tourists, providers of products and services in the destination are some of the most important factors for sustainable development. Hence, it is very important to emphasize the importance of sustainable development and to encourage them to act under its objectives. Only those tourist destinations that know how to manage their tourist area and make optimal use of its resources will be able to survive in the future.'

Although the goals of sustainable tourism development were looking at the broader perspective in the past, today they are more oriented towards the local community. They are focused on increasing tourist satisfaction and social-economic benefits, preserving natural and cultural heritage, and reducing the unpleasant impacts of tourism on the local community in general. The publication of the umbrella tourism organization World Tourism Organization (2005) entitled Making Tourism More Sustainable: A Guide for Policy Makers lists and describes 12 sustainable tourism goals:

1. Economic viability: maintaining the competitiveness of tourist destinations and business entities in order to achieve long-term economic advancement of the local community, and thus the satisfaction of the visitors;

2. Enhancing local prosperity: encouraging local entrepreneurship and increasing the positive socialeconomic effects on the life of the local community;

3. Improving quality of employment: ensuring and improving the conditions of employment in tourism, leading to an improvement in the quality of service rendered to tourists;

4. Achieving social equity: the need to ensure social equity, that is, a fair distribution of the economic and social benefits and opportunities arising from tourism throughout the destination;

5. Tourist fulfilment: ensure a satisfactory experience for tourists by providing security and no discrimination of any kind whatsoever;

6. Increasing the quality of local governance: more intense involvement of the local community in decision-making, planning, implementation and control of sustainable tourism goals;

7. Community well-being: improving and maintaining the quality of life of local communities, avoiding any form of social discrimination;

8. Cultural wealth: preservation and protection of cultural wealth and tradition of the destination;

9. Ensuring physical integrity: preserving and improving the quality of rural and urban space, taking care of protected areas, conducting education on the importance of environmental protection;

10. Conservation of biodiversity: protection of preserved natural areas, biodiversity, and habitat, flora and fauna while reducing the negative impact of tourism on nature;

11. Efficient use of resources: reducing the use of scarce and non-renewable resources in tourism activities, and increasing the use of recycling materials and renewable energy;

12. Ensuring environmental purity: minimizing air, water and land pollution, and more frequent use of eco-friendly transportation and recycling. 
From the foregoing, it can be concluded that all the sustainable development goals are interconnected and equally important for the implementation of a sustainable tourism development policy. They cover environmental, economic, and social factors, meaning that together they form a strategy important for the further progress of the destination. The islands have to be perceived and strategically defined as a unique geographical, strategic, and marketing unity in tourism. The sustainable development of tourism on the islands is the only opportunity for their revival because should tourism be unsustainable, it could destroy the natural and cultural heritage. Such a move would result in tourists being uninterested in arriving and spending holidays on the islands and thus damaging the quality of life in the area.

\section{Sustainable Development of Island Tourism in Croatia} 'The Croatian islands have great potential, not only for the development of the area but also for the overall development of the Republic of Croatia' (Vlada Republike Hrvatske, 2018, p. 3). The Republic of Croatia has outlined in several strategic documents the principle of sustainability as one of the basic principles of development. However, the specific campaign 'The Initiative of Islands' is especially described in sequence. 'The Initiative of Islands' is a campaign launched in 2015, bringing together various companies, organizations and associations from the Croatian islands which want to promote sustainable development and raise the quality of life on the islands. Representatives of the islands of Hvar, Šolta, Vis, Brač, Korčula, Olib, Lastovo, Mljet, Cres, Prvić, Lošinj, Krk and Silba are currently participating in this campaign.' The goal of the 'The Initiative of Islands' is to primarily educate its members on the importance of sustainable tourism development, which is being sought through employment, reinvestment, linking tourism with organic food production, etc. One way is to create a virtual platform that would provide the islanders with all the necessary information in one place. It is a very interesting and successful action, as evidenced by the fact that the launching of similar campaigns in other countries such as Greece and Spain is considered (Održivi turizam u Hrvatskoj, n.d.).
The islands have numerous opportunities for the development of sustainable tourism, but in the rest of Croatia and on the islands, tourism shows noticeable features of seasonality. Additional problems are the emergence of depopulation, the abandonment of traditional activities, and the reduced quality of life in the area. 'It is for this reason precisely that tourism is an activity that needs to be developed there in order to revitalize the islands and tourism and stimulate the development or renewal of other economic activities' (Zupanc et al., 2000, p. 134).

Vidučić (2007) states that Croatian island tourism needs to address certain issues such as:

1. How to protect the space so far preserved?

2. What are the advantages for the development of a particular region?

3. What are the limitations of development?

4. What role does government and local administration play in the development?

5. Should the development be construed on cultural, historical and economic acknowledgement or some new assumptions made?

6. How to create development that will not bring itself into collapse?

In the same way, the author states: 'Each of the Croatian islands is special and offers unique content, so for this reason, it is necessary to determine a development strategy individually, provided that the natural and cultural heritage is preserved. All this can be achieved slowly and with small investments, since large investments, especially in infrastructure, could adversely affect the life and environment of the island. The cooperation of the local community, unique island tourism supply and specific island entrepreneurship supported by state incentives are what the sustainable development of the Croatian islands should be about. The task of the island's tourist destination is to maintain its authenticity, culture and tradition and build its reputation upon, whereat sustainable development should endorse such a way of life' (Vidučić, 2007, p. 43). There are numerous benefits to sustainable tourism in the islands, and some of them are listed in Table 2 according to the principles of sustainable tourism. 
Table 2 Benefits of Sustainable Tourism Development of the Island According to Its Principles

\begin{tabular}{|c|c|c|}
\hline Environmental sustainability & Socio-cultural sustainability & Economic viability \\
\hline Ensures coastal environment integrity & Helps reduce depopulation & $\begin{array}{l}\text { Enables traditional island products } \\
\text { additional value }\end{array}$ \\
\hline $\begin{array}{l}\text { Ensures sustainable use of natural } \\
\text { resources }\end{array}$ & $\begin{array}{l}\text { Restores island old cultural customs } \\
\text { and activity }\end{array}$ & Improves demographic structure \\
\hline Protects natural protected areas & Advocates shareholders' collaboration & Raises island destination standard \\
\hline Controls and reduces pollution & Helps to resolve misunderstandings & Ensures better traffic connection \\
\hline $\begin{array}{l}\text { Cares for indigenous architecture and } \\
\text { rural island scenery }\end{array}$ & Improves life quality on the islands & $\begin{array}{l}\text { Reduces energy, transport and } \\
\text { communication costs }\end{array}$ \\
\hline
\end{tabular}

Notes Adapted from United Nations Environment Program (UNEP) (2010) and Faričić and Magaš (2004).

\section{Island Of Pag as a Sustainable Tourist Destination} General Characteristics of the Island of Pag

'The island of Pag is located between the Velebit Channel and Kvarnerić, and its surface is 284.56 square kilometres, making it the largest island in northern Dalmatia' (Faričić, 2003, p. 47). 'Pag is part of the northern Dalmatian island group, and with the longest coastline it is the fifth largest island in the Republic of Croatia. The Pag Bridge connects the island to the mainland, whereas the ferry connection between PriznaŽigljen and the catamaran route operating between Novalja and Rijeka are essential for traffic connectivity' (Lončar, 2009, p. 6).

'According to the administrative-territorial division, the island of Pag is the only island divided into two counties, and the main administrative, economic and transport centre of the island is the Town of Pag. The County of Zadar covers the central and southern parts of the island, which consists of the Town of Pag and the Municipality of Povljana, while the northern part of the island belongs to the County of Lika and Senj, i.e. the town of Novalja, with the settlements of Metajna, Zubovići, Kustići, Vidalići, Caska, Gajac, Stara Novalja and Potočnica' (Magaš, 2000, p. 35).

The special features of the island of Pag are numerous sources of drinking water streaming below the sea level from Velebit mountain, and the proximity of the mountain determines the climatic conditions on the island. Namely, although the Mediterranean climate is predominant on the island, the eastern part of the island is completely bare due to strong wind (Lončar, 2009).
Tourism Specificities of the Island of Pag

'The tourist advantage of the island of Pag and the underlying fundament on what [sic] Pag builds its brand is precisely the diverse cultural and natural heritage and numerous cultural and historical monuments. Among the most important features that Pag can be commended with appertain: the world famous Pag cheese, lace and costume, Benedictine monastery, the baškotin, ${ }^{1}$ Pag Cultural Summer, the Summer Carnival and Pag Folk Drama. The island thus offers its visitors numerous facilities for rest and enjoyment' (Grad Pag \& Institut za turizam, 2015, p. 63). According to the list of categorized tourist facilities from 2019 and island of Pag data, there are 12 hotels with a total of 1053 beds, 1 apartment hotel with 32 beds and 4 campsites with a total of 10,251 accommodation units on the island of Pag (Ministarstvo turizma i sporta Republike Hrvatske, n.d.).

The tourist boards of the Town of Pag and the Town of Novalja are one of the main promoters of the island, attracting potential tourists by organizing interesting events. According to the author of this paper, one of the most useful websites for visitors to the island is Visit Pag Island, which in one place offers all the services on the island that might interest tourists. For example, it offers general information about the island (economy, history and culture), possible accommodation, itineraries, activities and tours, interesting events, excursions, and gastronomy of the island of

\footnotetext{
${ }^{1}$ Type of sweet toast produced in the Benedictine monastery where it can only be purchased (see https://pag.hr).
} 
Table 3 Ranking of Novalja in the 'Top 10' Researches of the Croatian National Tourist Board for July 2019

\begin{tabular}{lc}
\hline 'Top 10' research & Ranking \\
\hline 'Top 10' destination in Croatia by total tourist & 7th place \\
turnover in July 2019 & \\
'Top 10' destination in Croatia by tourist camp- & 7th place \\
ing turnover in July 2019 & \\
'Top 10' destination in Croatia by family ac- & 4th place \\
$\begin{array}{l}\text { commodation in July } 2019 \\
\text { 'Top 10' destination in Croatia by non- }\end{array}$ & 4th place \\
commercial accommodation in July 2019 & \\
'Top 10' destination in Croatia by turnover of & 4th place \\
domestic tourists in July 2019 & \\
'Top 10' destination in Croatia by turnover of & 6th place \\
foreign tourists in July 2019 & \\
\hline
\end{tabular}

Notes Adapted from Hrvatska turistička zajednica (2019).

Pag. On Pag, there is a part of the island dedicated to those seeking peace and quiet for their vacation, but the island also offers numerous services for those eager for good fun. The world-renowned Zrće (Novalja) 'party destination' has been known for many years for attracting an increasing number of tourists, which is why it is a leader in occupancy of accommodations over the rest of the island. This is confirmed by the fact that according to the Croatian Tourist Board issue on statistical indicators of tourist turnover for the month of July (2019), Novalja is in almost every 'Top ${ }_{10}$ ' research $^{2}$ in the results by destination (Table 3 ).

'The strategic goal of tourism development on the island of Pag is to create a unique tourism product based on rich culture and historical heritage in order to diverge from other destinations. This is the origin of a vision of Pag as a sustainable destination that, according to the needs and expectations of highly segmented buyers of tourism products, such as sun and sea, sports and recreation, gastronomy, cultural, nautical and health tourism, provides a healthy and dynamic holiday. In addition, the quality of life of the lo-

${ }^{2}$ According to the information on the course of the season, which shows the indicators of tourist turnover achieved at monthly intervals, the Ministry of Tourism compiled a list of the 'Top 10' destinations according to different criteria.
Table 4 Principles of Sustainable Tourism on the Island of Pag

\begin{tabular}{ll}
\hline Principle & Item \\
\hline Spatial-environmental & Viability \\
& Use of responsible practice \\
\hline Social sustainability & Partnership \\
& Preserving the spirit of the place \\
\hline Economic viability & Innovation and quality \\
& Coordination \\
\hline
\end{tabular}

Notes Adapted from Grad Pag \& Institut za turizam (2015).

cal population, tradition and environmental concerns must not be forgotten. The island also has numerous opportunities to develop selective forms of tourism such as hunting and fishing, health, rural tourism and protected cultural heritage tourism' (Grad Pag \& Institut za turizam, 2015, p. 24).

\section{Principles of Sustainable Tourism Development on the Island of Pag}

'The tourism of the island of Pag is based on raising the quality and standard of living of the local population by promoting activities based on tradition and sustainable use of natural resources [...] The development of sustainable tourism on the island emphasizes environmental protection, culture of quality, the uniqueness of the destination, growth of entrepreneurship and stakeholder partnership' (Grad Pag \& Institut za turizam, 2015, p. 53). The strategic plan for tourism development of the town of Pag from 2016 to 2020 (Grad Pag \& Institut za turizam, 2015), defines the principles of sustainable tourism on the island of Pag, which are described below.

The environmental principle of sustainable development of the island defines the optimal way of using and managing the space, both natural and cultural heritage. It also involves caring for the preservation of development potential, the implementation of 'green' business practices, and encourages residents and visitors to reduce adverse environmental impacts. According to the document of the Utility Company $\mathrm{Pag}^{3}$ Strategy of Development of the Utility Company Pag

${ }^{3}$ Established in 1995, and performs activities such as collec- 
LLC from 2016 to 2020 (Komunalno društvo Pag, 2015), the main objective of environmentally sustainable development is the permanent preservation of originality and biodiversity, the conservation of aquatic and wetland habitats, and the avoidance and reduction of waste generation.

The social and cultural principle of the island aims to preserve the unique features of the local community such as the traditional costume of the Town of Pag, Pag lace protected by unesco, and various cultural manifestations such as the Pag Cultural Summer. The quintessence is the creation of a tourist offer in compliance with the 'spirit' of the destination and the life of the local community. At the core of the sociocultural principle is the principle of partnership, aimed at stakeholders' cooperation for the purpose of developing island tourism (Grad Pag \& Institut za turizam, 2015). Precisely this cooperation between stakeholders plays a very important role on the island since Pag is divided into two counties and is the only island where two different regional governments operate. In the above-mentioned paper, Bašić et al. (2015) propose the creation of a single destination management organization, that is, the Destination Management Organization (DMO), whose task would be to manage tourism throughout the island. Such an approach would very likely solve the problem of uneven development on the island.

'The goal of the economic principle is to increase the number of investment projects and the positive effects of economic activity on the environment. The innovation and quality of all business entities are key elements of competitive advantage. It is very important to align public and private projects with the goal, vision, and mission of the island tourism development and the focus is on several smaller sustainable investments' (Grad Pag \& Institut za turizam, 2015, p. 54).

According to the 'Town of Pag Activity Plan,' which is described in the strategic plan for tourism development of the town of Pag, some of the investments are the improvement of the system of tourist information centres, beach cleaning, development and im-

tion, treatment, distribution of water, etc. (see https://kdpag.hr/). provement of the hotel offer, development of health and tourist facilities, elaboration of detailed plans for the most important tourist zones on the island and others (Grad Pag \& Institut za turizam, 2015).

\section{Empirical Research}

Research Objective and Methodological Framework

This part of the paper describes the results of primary research that offer a holistic view on the issue of island sustainability and island tourism on the example of the island of Pag. Of particular interest is the question of whether respondents believe that the sustainability of the island develops under all three criteria/aspects of sustainable development - economic, socio-cultural, and environmental - and what importance they attach to each of these aspects. Cohen (2017, p. 26) states: 'Tourism researchers have related to the role of the islands' inhabitants in tourism development, but paid scarce attention to the wider effects of tourism penetration upon island societies. [...] Most tourism researchers show little concern for the effects of tourism on local socio-cultural change.' In this sense, an interview/survey questionnaire is structured, which consists of the same questions in order to be able to perform a comparative analysis. They are structured in such a way that the results of the research can be used to determine the basic limiting factors of sustainable tourism development on the island of Pag, and to assess their importance, according to the respondents. Furthermore, respondents were asked about the selection of the selective form of tourism that would most contribute to the development of off-season tourism in the function of sustainable development. The participants were asked to assess the extent of sustainable tourism development on the island of Pag, as well as to choose the principle according to which they believe that tourism on the island should be developed to the greatest extent. The questionnaire/interview consisted of 4 complex questions. The research has been carried out in a broader sense as part of an internal university project on the development of sustainable tourism at the Department of Economics, University of Zadar, Croatia, and in a narrower sense as part of the research for the master's thesis Island of Pag as a Sustainable Tourist Destination (Miletić, 2019). The primary re- 
search has been conducted by a method of combining expert interviews and surveys. Then, a comparative analysis of the research results has been performed using interviews and survey results. The research was conducted in August 2019 on the island of Pag. Key stakeholders in tourism on the island of Pag were examined, employed in the following institutions and organizations: information centres, hotels, tourist agencies and camps. An expert from the Tourist Board of the City of Pag was interviewed. A total of 21 respondents participated in the survey. The results of interviewing experts from the Tourist Board of the City of Pag are specifically separated and compared because it was assumed, since the Tourist Board is the umbrella organization for tourism development, its opinion aggregates the opinions of many other stakeholders members of the Tourist Board. Since the aim of the research was to look holistically at the issue of sustainability on the Island, the opinion of the representatives of the tourist community is of special importance for the goal of the research. Therefore, according to the authors, it should be singled out. The smaller number of respondents - tourism experts on the island in the survey can be partially justified by the fact that the island of Pag does not have a large number of commercial accommodation facilities, which makes the issue of sustainable tourism even more challenging.

\section{Research Results}

This section of the paper displays results of the survey and especially analyses the feedback of respondents from the Town of Pag Tourist Board. The first part of the analysis explores the greatest problems facing islands that hinder the development of sustainable tourism. There were five problems offered: mass tourism, lack of investment projects, uncontrolled apartmentisation, loss of quality labour in tourism and uneven tourist development of the island. Respondents rated 1 to 5 on the importance of each problem, noting that rating 1 meant that the problem was insignificant on the island, and rating 5 indicating that the problem was of the highest importance.

The first problem mentioned was mass tourism on the island of Pag, and the results of the assessment of importance by the respondents are shown in Figure 1.

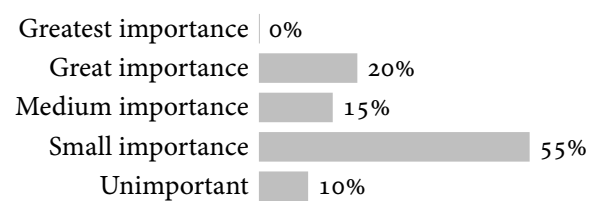

Figure 1 Assessment of Mass Tourism Importance on the Island of Pag

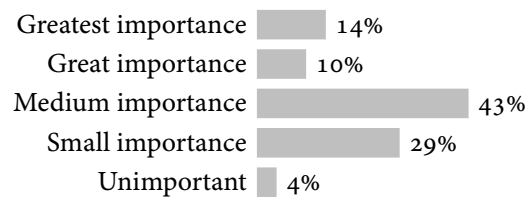

Figure 2 The Assessment of the Lack of Investment Projects Problem Importance on the Island of Pag

According to the results obtained, it can be concluded that mass tourism does not pose a great threat to the island of Pag. None of the respondents rated the massive scale with 5 , i.e. did not consider it to be a problem of the utmost importance. A respondent from the Town of Pag Tourist Board evaluated the mass tourism on the island with rating 4 , which means that such respondents considered this problem to be of great importance. However, the majority of respondents (55\%), who anonymously completed the survey, consider that mass tourism as an island problem is of little importance, i.e. their answers indicate they believe that there are bigger problems on the island than mass tourism.

Figure 2 shows the information on the problem of lack of investment projects on the island of Pag. Opinions of anonymous respondents were divided, as $43 \%$ rated this issue with 3 or of medium importance in scale, and $29 \%$ said the problem was almost insignificant where the island of Pag is concerned. Of the 21 respondents, $14 \%$ said that the lack of investment projects is of the greatest importance on the island. A respondent from the Town of Pag Tourist Board considers this to be of medium importance, which implies the need to solve it.

When it comes to the problem of uncontrolled apartmentisation, the respondents generally agree that this is one of the issues that need to be addressed more. 


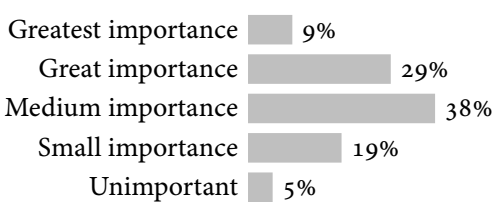

Figure 3 Assessment of Uncontrolled Apartmentisation Problem on the Island of Pag

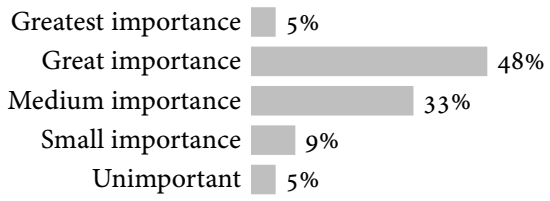

Figure 4 Assessment of the Loss of Quality Labour Problem in Tourism on the Island of Pag

$38 \%$ say it is a problem of medium importance, while $29 \%$ say that its importance is the greatest. Only 5\% of the respondents rated the problem of uncontrolled apartmentisation with 1 , meaning that such an issue does not pose a major threat to the island of Pag. It is very important to point out the answer of the respondent from the Town of Pag Tourist Board, who rated this problem with 5 , that is, assigned the highest importance to the uncontrolled apartmentisation among all mentioned problems in the survey.

According to the results of an empirical study on the loss of quality labour in tourism as a problem of the island of Pag, $48 \%$ of respondents described it as a problem of great importance, while $33 \%$ considered it to be of medium importance. $5 \%$ of those interviewed anonymously think that the problem is unimportant on the island, while $5 \%$ of the 21 respondents think the opposite, that is, the loss of good labour in tourism is a great problem on the island of Pag. The rest of the respondents, $9 \%$ of them, rated the problem of loss of quality labour in tourism as of small importance. The opinion of the respondent from the Town of Pag Tourist Board is in accordance with the opinion of 33\% of anonymous respondents, namely they consider it to be a problem of medium importance on the island of Pag. Recently, quality labour is leaving not only from the tourism industry but from all economic areas.

The last problem in the questionnaire, rated by the

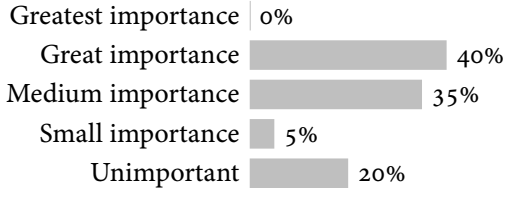

Figure 5 Assessment of the Uneven Tourist Development Problem on the Island of Pag

respondents with a score from 1 to 5 , was the problem of uneven tourist development of the island of Pag, and the results are presented in Figure 5.

When asked about the problem of uneven tourist development on the island of Pag, 21 respondents provided an answer, 20 of them anonymously, 1 respondent did not respond, and one respondent from the Town of Pag Tourist Board answered. Figure 5 shows that $40 \%$ of respondents think that this is an issue that needs to be addressed as soon as possible, that is, they described it as a problem of great importance on the island. Likewise, $20 \%$ think that this problem is completely unimportant. It is very important to emphasize the opinion of the respondent of the Town of Pag Tourist Board, who agrees with the opinion of $5 \%$ of anonymous respondents, that is, believes that the island has an almost even development of tourism.

The pronounced seasonality is one of the biggest tourism problems in the Republic of Croatia. According to the 'Croatia 365 ' project, tourist destinations should be promoted with their specific features in order to stimulate the off-season tourist movement. Also, in solving the above-mentioned problem, it is desirable to develop selective forms of tourism in destinations. The survey included the question of what point of advantage, or what endeavour, could reduce the seasonality in tourism of the island of Pag.

Respondents were given the possibility of multiplechoice, but a maximum of 3 . In Figure 6, development projects were ranked in order of importance by the opinions of anonymous respondents. According to the results, the advantage by which the island of Pag could be promoted to reduce seasonality is the development of rural tourism (61.9\% of respondents). The respondent from the Town of Pag Tourist Board cited the development of health tourism, construction of bicycle 


\begin{tabular}{r|r} 
Other & $0 \%$ \\
Developing business tourism & $19 \%$ \\
Building higher cat. hotels with additional services & $24 \%$ \\
Developing hunting and fishing tourism & $43 \%$ \\
Building bicycle paths and promoting cycling & $52 \%$ \\
Developing health tourism & $52 \%$ \\
Using its cultural heritage and tradition & $52 \%$ \\
Developing rural tourism & $62 \%$
\end{tabular}

Figure 6 Development Measures Aimed at Reducing the Seasonality of Tourism on the Island of Pag

\begin{tabular}{|c|c|}
\hline Economic Principle & $15 \%$ \\
\hline Social-cultural principle & $35 \%$ \\
\hline Economy principle & \\
\hline
\end{tabular}

Figure 7 Ranking the Importance of Sustainable Tourism Principles on the Island of Pag

paths and cycling, cultural heritage and tradition as a desirable way of promotion during the off-season period.

Figure 7 lists the respondents' answers on the importance of a particular principle of sustainable tourism development on the island of Pag.

According to the empirical survey, as many as 55\% of respondents believe that the island of Pag should be more environmental, $30 \%$ say it is a socio-cultural problem, and $15 \%$ say that it is the economic principle due to a problem of poor development of sustainable tourism on the island of Pag. The respondent from the Town of Pag Tourist Board agrees with the opinion of most anonymous respondents and responded that the environmental principle was one that the island should pay more attention to. Environmental care is an essential determinant for the further development of the island, while preserving the quality of the environment is a prerequisite for long-term sustainable development. The figure also indicates to what extent sustainable tourism is currently developed on the island of Pag.

According to the results of the anonymous survey, $47.6 \%$ of respondents stated that sustainable tourism is developing poorly on the island, while $19 \%$ believe that the island of Pag is doing very well in leading the sustainable tourism development policy. None of the respondents answered that sustainability is developing

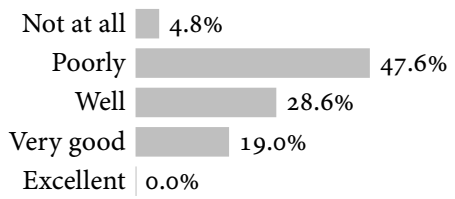

Figure 8 Development of Sustainable Tourism on the Island of Pag

excellently on the island, and particularly interesting is the response of the respondent from the Town of Pag Tourist Board who believes that sustainable tourism is not developing at all in this region.

\section{Discussion}

The conducted empirical research provided intriguing answers, and the opinions of the respondents confirm or respectively reject the hypothesis stated: The island of Pag is successfully implementing a sustainable tourism policy, regardless of the problems encountered as a tourist destination. According to the results of the empirical research, the respondents described the development of sustainable tourism on the island of Pag as very bad, and this is further confirmed by the respondent from the Town of Pag Tourist Board, who believes that sustainability does not apply at all in the process of island development. For this reason, the hypothesis is rejected. In order to change this situation, it is first of all necessary to solve issues such as uncontrolled apartmentisation, the loss of quality tourism labour and inequalities in island development, which were rated as of great importance by the respondents, in order for sustainability to develop. By establishing a unique organization of destination management, these limitations could be resolved, and sustainability could develop smoothly and properly. The backbone of tourism sustainability is found in three principles that must be equally promoted, namely, the environmental, economic, and socio-cultural principles. Most respondents $(55 \%)$ consider the environmental principle to be the least developed principle on the island of Pag. This is another argument confirming the poor development of sustainable tourism in the area. However, in the period after the primary research, two significant changes were made. They are described below. 
The first DMOs as the central destination management organizations have entered the legislation of the Republic of Croatia. The amended 'Law on Tourist Boards and the Promotion of Croatian Tourism' ('Zakon o turističkim zajednicama i promicanju hrvatskog turizma,' 2020) states: (Art. 1): 'This Law, according to the model of destination management organization, regulates the system of tourist boards, organization, tasks, and manner of work of tourist boards and basic principles of their financing and management.' (Art. 2): '2. Destination management organization is defined as an organization that brings together stakeholders from the public, private and civil sectors for the strategic and operational management of the destination and the realization of a common, previously agreed vision. 3 . The principle of destination management implies the tourism activities of stakeholders, unitary purposeful business cooperation, to develop an integrated and competitive destination product.'

Furthermore, key Pag tourist stakeholders have united to uniquely brand the island, which they achieved by activating the Visit Pag portal (http://www.visit -pag.com), and to implement other integrated projects. For example, the leaders of Pag's tourist towns signed an Agreement on the association of local tourist communities from the island of Pag in the implementation of the project 'Development of Outdoor Tourism on the Island of Pag' which aims to develop and shape the island into a unique, harmonized and marketestablished destination. The media state: 'It is, we can freely say, a historical moment in which all the island's tourist boards signed such a multi-year joint project for the first time, which is important for tourism and quality offer of the entire island of Pag' (Udruživanje lokalnih turističkih zajednica u provedbi projekta 'Razvoj outdoor turizma na otoku Pagu,' n.d.). The signing of this Agreement was approved by the Commission of the Ministry of Tourism of the Republic of Croatia, which provided the preconditions for applying for the Fund for United Tourist Boards of certain areas for joint development of tourism products and destination promotion, established in 2020. The Agreement presents, in detail, the activities that should, with the financial support of the Ministry of Tourism of the Republic of Croatia, be implemented by the end of
2023. 'This is a logical continuation of the previous continuous cooperation, since the tourist boards of the island of Pag have more than three years ago set out on a joint path of cooperation under the motto "Pag Moon Island - A Common Vision". This fully respects the intention of the Ministry of Tourism of the Republic of Croatia to encourage project association of tourist boards in an area because tourism exceeds administrative boundaries and therefore legislative changes have been made to enable joint presentation and development of destinations which, although special in their way, form a complete tourist story' (Udruživanje lokalnih turističkih zajednica u provedbi projekta 'Razvoj outdoor turizma na otoku Pagu,' n.d.).

\section{Conclusion}

Sustainable tourism development implies responsible management of the area, with an emphasis on natural and cultural heritage, and aims to meet the needs of tourists and needs of current and future local communities. With the development of sustainability, destinations maximize their potential while creating a balance between three important principles: environmental, economic and socio-cultural. For this reason, sustainability has recently been one of the most commonly used terms in tourism.

Croatia is a destination that repeatedly attracts many tourists for its beauty. Still, a massive scale tourism and seasonality problem emerges and hinders the development of sustainability. Through various projects, the most famous being 'Croatia 365', Croatia is struggling against the seasonality problem. Due to its authenticity, the Croatian islands are one of the great potentials in terms of tourism. One of its assets is the island of Pag, building its tourist identity on cheese, salt and lace as traditional elements. On the other hand, the island brand is being also built by Novalja, as a world-famous party destination.

According to the empirical research presented in this paper, sustainable tourism is developing very poorly on the island of Pag. It is so due to numerous limitations, such as excessive apartmentisation, loss of quality labour in tourism, massive scale tourism, and others. Among the significant problems that make sustainable tourism poorly developed is the division of 
islands in two counties and generally uneven development. As many as $47.6 \%$ of the respondents who participated in the primary survey presented in this paper believe that sustainable tourism is developing very poorly on the island. One of the important measures in the area of sustainability is the idea of establishing a DMO, an organization that would take care of tourism development, based on which the above problems would be minimized, and the development of sustainable tourism would proceed. Consequentially, the Dмо would have a broader perspective, and pay attention to the balance among all the principles, especially the environmental one, which the respondents rated as the least tended principle in the island of Pag. The most important task of the DMO in Pag would be to ensure a balanced development of tourism in all parts of the island. By establishing such a unique organization of destination management, sustainability could be developed smoothly and properly. In this sense, the Republic of Croatia has already taken certain steps, both in improving the legislation in the field of destination management and on the island of Pag, where tourism stakeholders have joined forces to unite marketing activities for sustainable tourism development.

As a major limitation of the primary research conducted in this paper, the authors emphasize the fact that the survey did not cover all tourist stakeholders on the island. The authors recommend further similar research and comparisons between the developments of island tourism sustainability in Croatia with other competitive island tourist destinations. As a scientific implication of this paper, the authors point to the quest for a unique model of sustainable tourism development in island tourist destinations and a contribution to the scientific debate in this regard. As practical implications, the results of the research presented here can serve policymakers at all levels, as well as the strategic management of tourism entities on the island in formulating guidelines for further development.

Finally, it should be emphasized that the sustainability and sustainable development of tourism themes, especially in the islands as extremely fragile geographical, economic and socio-cultural entities, is of particular importance. The complexity of the term sustain- ability is best described by a quote from the author Smolčić Jurdana (2003, p. 161): 'Sustainable development is not a current state but a never-ending process.'

\section{References}

Apostolopoulos, Y., \& Gayle, D. J. (Eds.). (2002). Island tourism and sustainable development: Caribbean, Pacific, and Mediterranean experiences. Praeger.

Bašić, T., Krajnović, A., \& Bosna, J. (2015). Neke smjernice za brendiranje otoka Paga u funkciji razvoja turizma. Holon: postdisciplinaran znanstveno-stručni časopis, 5(1), 92-107.

Bramwell, B., \& Lane, B. (1993). Sustainable tourism: An evolving global approach? Journal of Sustainable Tourism, 1(1), 1-5.

Breslauer, N., Gregorić, M., \& Hegeduš, I. (2015). Održivi razvoj turizma u Međimurskoj županiji. Obrazovanje za poduzetništvo - E4E, 5(1), 99-109.

Brown, K. G., \& Cave, J. (2010). Island tourism: Marketing culture and heritage. International Journal of Culture, Tourism and Hospitality, 4(2), 87-95.

Butler, R. (1999). Sustainable tourism: A state-of-the-art review. Tourism Geographies, 1(1), 7-25.

Carlsen, J., \& Butler, R. (2011). Island tourism: Towards a sustainable perspective. C A B I.

Cohen, E. (2017). Towards a convergence of tourism studies and island studies. Acta Turistica, 29(1), 7-31.

Čavlek, N., \& Vukonić, B. (2001). Rječnik turizma. Masmedia.

Faričić, J. (2003). Otok Pag na starim kartografskim prikazima. Geoadria, 8(1), 47-126.

Faričić, J., \& Magaš, D. (2004). Suvremeni socio-geografski problemi malih hrvatskih otoka - primjer otoka Žirja. Geoadria, 9(2), 125-158.

Grad Pag \& Institut za turizam. (2015). Strateški plan razvoja turizma Grada Paga za razdoblje od 2016.-2020. godine. https://www.pag.hr/index.php/gradska-uprava/ savjetovanje-s-javnoscu/strateski-plan-razvoja-turizma

Hrvatska turistička zajednica. (2019). Informacija o statističkim pokazateljima turističkog prometa - srpanj 2019. https:/htz.hr/hr-HR/informacije-o-trzistima/ informacije-o-tijeku-sezone

Jadrešić, V. (1999). Proturječja i negativne pojavnosti u turizmu. Tourism and Hospitality Management, 5(1-2), 5567.

Jafari, J. (1989). Sociocultural dimensions of tourism: An English language literature review. Tourism as a Factor of Change: A Sociocultural Study, 1(1), 17-6o.

Klarin, T. (2017). Kreiranje modela održivog razvoja turizma 
u urbanim destinacijama Republike Hrvatske [Unpublished doctoral dissertation]. Sveučilište u Rijeci.

Kokkranikal, J., McLellan, R., \& Baum, T. (2003). Island tourism and sustainability: A case study of the Lakshadweep Islands. Journal of Sustainable Tourism, 11(5), 426447.

Komunalno društvo Pag. (2015). Komunalno društvo Pag: strategija razvoja 2016.-2021. https://kd-pag.hr/images/ pdf/strategijarazvoja.pdf

Krajinović, V. (2015). Propitivanje ključnih izazova u mjerenju održivog razvoja turizma. Acta Turistica, 27(1), 6391.

Krstinić Nižić, M., \& Drpić, D. (2013). Model for sustainable tourism development in Croatia. V 2st International Scientific Conference Tourism in South East Europe 2013; Crisis - A Challenge of Sustainable Tourism Development (pp. 159-173). University of Rijeka, Faculty of Tourism and Hospitality Management Opatija.

Krstinić Nižić, M., \& Fugošić, N. (2019). Integrated sustainable development on a local level - The Island of Krk as an example. Pomorski zbornik, 56(1), 89-108.

Lambert, E. (2009). Nature island tourism: Applying an ecotourism sustainability framework to the island of Dominica [Unpublished master's thesis]. University of Waterloo.

Lim, C. C., \& Cooper, C. (20o8). Beyond sustainability: Optimising island tourism development. International Journal of Tourism Research, 11(1), 89-103.

Lončar, N. (2009), Geomorphologic regionalization of the central and southern parts of Pag Island. Geoadria, 14(1), 5-25.

Magaš, D. (200o). Contribution to the knowledge of the geographical characteristics of the Pag island. Geoadria, 5(1), $5-48$.

Mai, T., \& Smith, C. (2015). Addressing the threats to tourism sustainability using systems thinking: A case study of Cat Ba Island, Vietnam. Journal of Sustainable Tourism, 23(10), 1504-1528.

Mikačić, V. (1994). Otočni turizam Hrvatske. Društvena istraživanja - časopis za opća društvena pitanja, 3(12-13), 517-529.

Miletić, N. (2019). Otok Pag kao održiva turistička destinacija [Unpublished master's thesis]. Sveučilište u Zadru.

Ministarstvo turizma i sporta Republike Hrvatske. (N.d.). Kategorizacija. Retrieved 20 November 2019 from https: //mint.gov.hr/kategorizacija-11512/11512

Ng, S. I., Chia, K. W., Ho, J. A., \& Ramachandran, S. (2017). Seeking tourism sustainability - A case study of Tioman Island, Malaysia. Tourism Management, 58(c), 101-107.
Održivi turizam u Hrvatskoj. (N.d.). Pokret otoka. http:// www.odrzivi.turizam.hr/default.aspx $?$ id $=5746$

Popesku, J. (2011). Menadžment turističke destinacije. Univerzitet Singidunum.

Smolčić Jurdana, D. (2003). Prednosti i ograničenja primjene koncepcije održivog razvoja turizma, doktorska disertacija [Unpublished doctoral dissertation]. Sveučilište u Zagrebu.

Sunara, Ž., Jeličić, S., \& Petrović, M. (2013). Održivi turizam kao konkurentska prednost Republike Hrvatske. Zbornik radova Medimurskog veleučilišta u Čakovcu, 4(1), 83-88.

Udruživanje lokalnih turističkih zajednica u provedbi projekta 'Razvoj outdoor turizma na otoku Pagu.' (N.d.). Morski.hr. https://morski.hr/2020/o6/12/pag -udruzivanje-lokalnih-turistickih-zajednica-u-provedbi -projekta-razvoj-outdoor-turizma-na-otoku-pagu/

United Nations Environment Program. (2010). UNEP annual report 2009: Seizing the green opportunity [Brochure].

Vidučić, V. (2007). Održivi razvoj otočnog turizma Republike Hrvatske. Naše more: znanstveni časopis za more $i$ pomorstvo, 54(1-2), 42-48.

Vlada Republike Hrvatske. (2018). Izvješće o učincima provedbe zakona o otocima u 2017. godini. https://razvoj.gov .hr/dokumenti/10

Vlahović, D. (2001). Koncepcijski okvir politike razvitka otočnoga turizma. Ekonomska misao i praksa, 10(2), 213231.

Vukonić, B. (2010). Je li održivost upitna? Acta turistica nova, 4(1), 33-42.

World Tourism Organization. (1998). Guide for local authorities on developing sustainable tourism. https://www.e -unwto.org/doi/book/10.18111/9789284402809

World Tourism Organization. (2005). Making tourism more sustainable: A guide for policy makers. https://www.e -unwto.org/doi/book/10.18111/9789284408214

Zakon o turističkim zajednicama i promicanju hrvatskog turizma. (2020). Narodne novine, (42). https://www .zakon.hr/z/342/Zakon-o-turisti\%C4\%8Dkim -zajednicama-i-promicanju-hrvatskog-turizma

Zupanc, I., Opačić, V., \& Nejašmić, I. (200o), Utjecaj turizma na demografska kretanja hrvatskih otoka. Acta Geographica Croatica, 35(1), 133-145. 